\title{
Distribution of the Ghrelin Hormone Producing Cells in the Gastro- intestinal Tract of Some Birds (Immunohistochemical Study)
}

\author{
Eidaroos H., ${ }^{1}$ Y.Yoshimura ${ }^{2}$ and Seham A.Helmy ${ }^{1}$ \\ ${ }^{1}$ Department of Cytology and Histology, Faculty of Veterinary Medicine, Suez Canal University and ${ }^{2}$ Gradu- \\ ate School of Biosphere Science, Hiroshima University. \\ E-mail: mohamedtalaat25@yahoo.com
}

With 26 figures

\begin{abstract}
Ghrelin hormone is a novel 28 - amino acid has recently discovered in birds in 1999. Ghrelin is a hormone produced by endocrine cells in the gastrointestinal tract. It stimulates growth hormone secretion, promotes food intake and energy expenditure. The distribution and morphologic characteristics of ghrelin - containing cells in the gastrointestinal tract of goose, ducks, chicken, quails and ostrich was investigated by immunocytochemistry. Ghrelin - immunopositive (ip) cells were located in the mucosa of the proventriculus, duodenum, jujenum, ileum and cecum of goose and duck, while in chicken, the ghrelin positive cells were mainly localized in the proventriculus and few cells were scattered in the small and large intestine. In quail and ostrich, the cells only found in the proventriculus. The numbers of the positive cells were numerous in goose and duck, than that in the chicken, quails and ostrich.
\end{abstract}

\section{Key Words}

Ghrelin hormone. Gastrointestinal tract, Birds

\section{Introduction}

Ghrelin is a peptide identified as an endogenous ligand for the growth hormone secretagogue receptor (Moesgaard et. al., 2004).

Kojima et al., (1999), Date et al., (2000), Seoane et at., (2000), Yamazaki et al., (2002) Boudesteyn et. al., (2002), Inui et. al., (2004) and Moesgaard et. al., (2004) said that, ghrelin is a hormone produced by endocrine cells in the stomach. Ghrelin stimulates the secretion of growth hormone, stimulates gastric-acid production and stimulate the appetite. Furthermore, feeding status seems to influence plasma ghrelin levels, as these are increased during fasting, whereas feeding and oral glucose intake reduce plasma ghrelin.

J. vet. anat.
Received March 2008; accepted for publication April

Inui et. al., (2004) said that, ghrelin stimulates appetite and induces a positive energy balance leading to body weight gain.

Murray et. al., (2003) stated that, ghrelin released from the stomach, it stimulates lactotroph and corticotroph secretion, increases appetite and adiposity. Baudet and Harvey (2003) said that, the intravenous administration of human ghrelin to immature chickens promptly increased the circulating $\mathrm{GH}$ concentration (within $10 \mathrm{~min}$ ), although this was transitory and was only maintained for $20 \mathrm{~min}$.

Korbonits et. al., (2004) stated that, ghrelin is brain-gut peptide with growth hormone-releasing and appetite-inducing activities. It is mainly secreted from the stomach mucosa but it is also expressed widely in different tissues and therefore may have both endocrine and paracrine effects.

Reiko et. al., (2002) stated that, a few ghrelinproducing cells was observed mainly in the proventriculus of the hatching chicken and numerous in the proventriculus of the adult chicken. Also few cells were detected in pylorus and duodenum of the adult chicken.

Ahmed et. al., (2002) showed that ghrelinimmunopositive (ghrelin-ip) cells exist in the chicken hypothalamus but not in the chicken proventriculus.

Masuda et. al., (2000), Wren et. al., (2000), Ariyasu et. al., (2001), Asakawa et. al., (2001), Date et. al., (2001), Inui (2001), and Nakazato et. al., (200I) reported that, ghrelin produced in the stomach is a major source of plasma ghrelin and play an important role in these functions. Rat ghrelin cells were found to be localized in the mucosa of the stomach, duodenum, ileum, cecum and colon but not in the myenteric plexus, and they can be classified into open- and closed-type cells (Ichiro et, al., 2002 and Sakata et, al., 2002). Date et, al., (2000) demonstrated that, the greatest amount of ghrelin contents were found in the stomach and the smaller amounts were found in the small and large intestines.

Takahiro et, al., (2001) mentioned that, the plasma ghrelin concentration in cows decreased significantly $1 \mathrm{~h}$ after feeding, and then recovered to prefeeding levels. 


\section{Materials and methouds}

This work was carried out on the gastrointestinal tract of five geese, five balady ducks, five white chickens, five quails and two ostrich. The specimens from the different parts of the gastrointestinal tract were taken immediately after sloughtering and fixed in Bouin's solution. The specimens were dehydrated in ascending grade of alcohol, clearing in xylene and imbedded in paraffin wax. $3-5 \mu \mathrm{m}$ thick were obtained and subjected to hematoxyline and eosin as general histological stain and immumohistochemical reaction for detection of ghrelin immune positive ip cells.

\section{Immumohistochemistry:}

Immumohistochemical detection of ghrelin producing cells using rabbit anti-ghrelin serum (no. 603) was carried out by the avidin-biotin-peroxidase complex $(A B C)$ methods. The immumohistochemical staining was performed basically according to the previously reported procedure (Sakai et al., 1994).

- Briefly, the sections were deparaffinized with xylene and rehydrated through descending concentrations of ethanol. The sections were bring to water, then washed in phosphate buffer solution (PBS), ph 7.4

- The sections were incubated with antighrelin serum (antibody) diluted 1:150000 in PBS for 2 hours at room temperature.

- The sections were washed in PBS three times, 5 minute for each.

- The sections were incubated for 1 hour at room temperature in Anti-rabbet immunoglobulin G (sigma 1: 200) in PBS buffer.

- The sections were washed in PBS three times 5 minute for each.

- The sections were incubated for 1 hour with an avidin-biotin-peroidase complex ( Vectastain ABC kit). $10 \mu \mathrm{m}$ avidin $+10 \mu \mathrm{m}$ biotin in $1 \mathrm{ml}$ PBS

- The sections were washed in PBS three times 5 minute for each.

- The sections were reacted in $0.2 \% 3-3-$ diaminobenzidine-tetrachloride (DAB) mixed with $0.0006 \% \mathrm{H} 2 \mathrm{o} 2$ in $0.05 \mathrm{M}$ Tris$\mathrm{Hcl}$ buffer, ph 7.6 for 30 second to detect immunostaining (coloring agent).

- Washing with distilled water, then the section were dehydrated with a grade of ethanol, clearing in xylene, mounting and view under a light microscope.

- A confirm test was used for sure detection whether these cells ghrelin ip cells or not by using immunized-rabbit serum instead

J. vet. anat. of anti-ghrelin serum (antibody) and then complete the same steps.

\section{Results}

\section{General histology:}

This study give an idea about the general histological structure of the gastrointestinal tract in different birds (geese, balady ducks, chickens, quails and ostrich). The gastrointestinal tract consists of stomach (proventriculus and gizzard), small and large intestine.

\section{A- Proventriculus}

The proventriculus consists of tunica mucosa, tunica submucosa, tunica muscularis and serosa (Fig: 1-A). The mucosa covered externally by thin layer of cuticle and it consists of an epithelial layer resting on a thin basement membrane, a lamina propria and a muscularis mucosa. The mucosa throw into folds, from the base of these folds simple to branched tubular mucosal gland extended. Tubulo-alveolar submucosal gland were found in the submucosa and open by a papilla on the mucosal surface. The submucosal glands are distributed throughout the entire organ in geese, balady ducks, chickens \& quails except in ostrich it confined to a slipper-shaped area along the dorsolateral walls of the proventriculus.

\section{B- Gizzard}

The gizzard covered with a thick and hard cornified layer (Fig: 1-B). The mucosa consists of lamina epithelialis (simple columnar epithelium), lamina propria (contain simple to branched tubular gland), there are no lamina muscularis mucosa, the tunica submucosa is thick and formed from dense fibrous connective tissue. The tunica muscularis is very thick to support the mechanical force of grinding.

\section{C-Intestine}

The intestine consists of small intestine [duodenum (Fig:1-C), jejunum (Fig:1-D) \& ileum (Fig:1-E)] and large intestine [caecum (Fig: $1-F)$, colon \& rectum]. The mucosa of the intestine is thrown into villi which show a marked variation in density, shape and size in the different regions of the intestine. In which the villi are numerous and best developed in the small intestine and diminish until only few small villi are seen in the ceca and rectum. The shape of the villi will differ according to the bird as in chicken the duodenal villi are long branched leaf-like and decrease in height toward the large intestine. In quails the duodenal villi are finger-like with rounded end but the jejunal villi are long \& tongue shape. In ostrich the duodenal villi are long branched forming labyrinthine surface.

\section{Distribution of ghrelin-immunopositive cells}


Ghrelin cells were observed in the gastrointestinal tract (proventriculus, duodenum, jejunum, ileum, cecum, colon and rectum, but not observed in the gizzard. Ghrelin cells were found in the mucosal layer of all the examined regions. Two types of ghrelin cells were found; i.e. closed-type cells (rounded cells) (Fig: 8-B) and cells with triangular or elongated shapes and with apical cytoplasmic process (opened type cells) (Fig: 10-C), indicating that, ghrelin cells can be classified into two cell types. The distribution of ghrelin-immunopositive ip cells will be differ in the birds. The goose proventriculus shows high density of ghrelin ip cells were seen in the mucosal (Fig: 2-A) and submucosal glands (Fig: 2-A\&B). The ghrelin cells were concentrated at the base of the mucosal glands, but in the submucosal glands the cells were concentrated around the lumen and at its margin (Fig: 2A). Also the ip cells observed in the intestinal villi and the intestinal glands of the duodenum (Fig: 3A), jejunum (Fig: 3-B), ileum (Fig: 3-C), cecum (Fig: 4-A), colon (Fig: 4-B) and rectum (Fig:4-C), but the density of the cells is low in the small intestine then increase in the large intestine (Fig: 3-B\& 4-B). In duck the ip cells were seen as few number in the mucosal gland and distribute equally in the submucosal glands (Fig: 5-A) of the proventriculus. Low density of cells were observed in the jejunum (Fig: 6-A) and ileum (Fig: 6-B) but the density increase in colon (Fig: 7-A) and rectum (Fig: 7-B). In chicken the number of the ip cells were low than that found in goose and duck, and observed in the base of the mucosal glands (Fig: 8-A) and around the lumen of the submucosal glands (Fig: 8-B) of the proventriculus. There were a few cells scattered in the small and large intestine (Fig: 9-A\&B). In quail and ostrich, the ghrelin ip cells were only detected in the mucosal and submucosal glands of the proventriculus (Fig: 10-A\&B\&C), in which they distributed allover the submucosal glands. There were no differences in immunoreactivities of ghrelin cells in various regions of gastrointestinal tract of geese, balady ducks, chickens, quails and ostrich.

\section{Discussion}

The mucosal glands vary from simple to branched tubular glands this finding is in agreement with Hodges (1974) and Hoda (1985) in fowl, Elzoghiby (2000) in turkey, Salem (1982) in duck and Bezuidenhout, et al., (1990) and Seham (2004) in ostrich.

The submucosal glands are distributed throughout the entire organ in geese, balady ducks, chickens \& quails except in ostrich it confined to a slippershaped area along the dorsolateral walls of the proventriculus glands, this finding is in agreement with Hodges (1974) and Hoda (1985) in fowl, Hoda (1982) in duck, Shafika (1989) in Pigeon and Bezuidenhout et al., (1990) and Seham (2004) in ostrich.

The mucosa of the intestine is thrown into villi which show a marked variation in density, shape and size in the different regions of the intestine. The shape of the duodenal villi in chicken are long branched leaf-like and decrease in height toward the large intestine this result agree with Hoda (1985) in fowl. In quails the duodenal villi are finger-like with rounded end but the jejunal villi are long \& tongue shape this result agree with Pfeiffer et, al., (1975) in quail and pigeon. In ostrich the duodenal villi are long branched forming labyrinthine surface this result agree with Bezuidenhout et, al., (1990) and Seham (2004).

The hypothalamic regulation of $\mathrm{GH}$ secretion in birds differs significantly from that in mammals (Harvey 1993), but ghrelin has recently been shown to increase plasma $\mathrm{GH}$ concentrations in immature chickens, (Ahmed et, al., 2002, Kaiya el, al., 2002). Although ghrelin directly stimulates $\mathrm{GH}$ release from mammalian pituitary cells (Kojima et, al., 1999, Yamazaki et, al., 2002), it also has hypothalamic sites of action (Date et, al., 2000, Tannenbaum \& Bowers 2001, Tolle et, al., 2001, Tamura et, al., 2002, Wren et, al., 2002).

The numbers of the positive cells were numerous in goose and duck, than that in the chicken, quails and ostrich, this cells produce ghrelin hormone which stimulates food intake, increase the appetite and stimulates growth hormone secretion, inducing a positive energy balance leading to body weight gain. These results explain the fact that the goose and duck having a habit of increase the food intake and the growth rate than that in chicken, quails and ostrich.

Ghrelin cells can be classified into two cell types, closed-cells and opened-cells. These two types of cells showed similar staining, and no marked differences in immunoreactivities. These results agree with the results of Ichiro et, al., (2002) in the gastrointestinal tract of rat.

In goose and duck the ghrelin ip cells were numerous in the proventriculus and in the small and large intestine, in chicken, the cells were numerous in the proventriculus, but a few cells were scattered in the small and large intestine. In quail and ostrich, the ghrelin cells were only detected in the mucosal and submucosal glands of the proventriculus. These results agree with Date et, al., (2000) and Ichiro et, al., (2002) which saied that the cells in rats were most dense in the stomach 
body, and low densities of ghrelin cells were found in the other examined regions (duodenum, ileum, cecum and colon).

The ghrelin cells were concentrated at the base of the mucosal glands and around the lumen of the submucosal glands in the proventriculus of goose and chicken. In duck, quail and ostrich the (ip) cells were seen as few number in the mucosal gland and distribute equally in the submucosal glands of the proventriculus. Reiko et, al., (2002) found numerous ip cells in the middle of the mucosal layer of the chicken proventriculus than at the base of these layer. Most of the cells were roundshaped cells (closed-type), that were not in contact with the lumen. Sakata et, al., (2002) observe the ghrelin cells in the glandular base of the rats stomach until 2 weeks of age and localized in the glandular base to the body of the fundic gland at 3 weeks of age. But Ichiro et, al., (2002) in rats stomach detect the ghrelin cells in the glandular base to body of the fundic gland, and a few cells were observed in the glandular neck.

The ip cells observed in the intestinal villi and the intestinal glands of the duodenum, jejunum, ileum, cecum, colon and rectum of goose duck and chicken, this results agree with that of Date et, al., (2000) and Ichiro et, al., (2002) which detect the cells in the epithelia of the intestinal villi and the crypts of rats intestine.

\section{References}

Ahmed, S. and S. Harvey (2002): Ghrelin: a hypo thalamic GH-releasing factor in domestic fowl (Gallus damesticus). Journal of Endo crinology. 172, 117-125.

Ariyasu, H.; K. Takaya; T. Tagarni; Y. Ogawa; K. Hosoda; T. Akamizu; M. Suda; T. Koh; K. Natsui; S. Toyooka; G. Shira kami; T. Usui; A. Shimatsu; K. Doi; $H$. Hosoda; M. Kojima; K. Kangawa and K.Nakao (2001): Stomach is a mjor source of circulating ghrelin, and feeding state determines plasma ghrelin-like im munorcactivity levels in humans- Journal of Clinical Endocrinology and Metabolism 86, 4753-4758.

Asakawa, A.; A. Inui; T. Kaga; H. Yuzuriha; T. Na gata; N. Ueno; S. Makino; M. Fujimiya; A. Niijima; MA. Fujino and M. Kasuga (2001): Ghrelin is an appetite-stimulatory signal from stomach with struc tural resemblance to motilin. Gastroenterolpgy 120 337-345.

Baudet, M. L.; and S. Harvey (2003): Ghrelininduced $\mathrm{GH}$ secretion in domestic fowl in vivo and in vitro. Journal of Endocrinology. 179, 97-105.
Bezuidenhout, A. J. and G. Van Aswegen (1990): A light and immuno-cytochemical study of the gastro-intestinal tract of the ostrich (Struthio camelus). On derste poort Journal of Veterinary Research 57, 37-48.

Boudesteyn, J.; $K H$, van der Leest and AJ. van der Lelij (2002): Ghrelin, an important hormone produced by the stomach. Ned Tijdschr Geneeskd. Oct 12;146 (41) : 1929-33.

Date, Y.; M. Nakazato; N. Murakami; M. Kojima; K. Kangawa and S. Matsukura (2001): Ghrelin acts in the central nervous system to stimulate gastric acid secretion. Bio chemical and Biophyskal Research Com munications 280 904-907.

Date, Y.; N. Murkami; M. Kojima; T. Kuroiwa; S. Matsukura; K. Kangawa and M. Nakaza to (2000): Central effects of a novel acy lated peptide, ghrelin, on growth hor mone release in rats. Biochemical and Biophysical Research Communictions. 275, 477- 480.

El-Zoghby, I. M. (2000): Histological and histo chemical studies of the digestive tract of turkeys at different ages. PH. D. Thesis, Fac. Vet, Med. Zagazig University (Ben ha).

Harvey, S. (1993): Growth hormone secretion in poikilotherms and homeotherms. In The Endocrinology of Growth, Development and Metabolism in Vertebrates, pp 151182. Eds PKT Pang, M, Schriebman \& CG Scanes. New York: Academic Press.

Hoda, F. (1982): Micromorphological studies on the oesophagus and stomach of the growing Sudanese ducks. M. D. Thesis, Fac. Vet, Med. Zagazig University.

Hoda, F. (1985): Histological and histochemical studies on stomach and intestine of Fayomi fowl with special reference to age and ration variations. PH. D. Thesis, Fac. Vet, Med. Zagazig University.

Hodges, R. D. (1974): The histology of fowl. $1^{\text {st }}$ ed., University of London Academic Press, London, New York. San Francisco Pg. 4588.

Ichiro, S.; N. Kazuaki; Y. Mami; M. Maki; H. Yui ji ro; K. Kenji and S. Takafumi (2002): Ghrelin-producing cells exist as two types of cells, closed- and opened-type cells, in the rat gastrointestinal tract. Peptides 23, 531-536.

Inui, A.; (2001): Ghrelin: an orexigenic and soma totrophic signal from the stomach. Nature Reviews. Neuroscience. 2, 551-560.

Inui, A.; A. Asakawa; CY. Bowers; G. Mantova ni; A. Laviano; M. Meguid and M. Fuji 
miya (2004): Ghrelin, appetite, and gastric motility: the emerging role of the stomach as an endocrine organ. FASEB J. Mar;18 (3) : 439-56.

Kaiya, H.; S. van der Geyten; M. Kojima; H. Ho soda; Y. Kitajima; M. Matsumoto; $S$. Geehssen; VM. Darras and K. Kangawa (2002); Chicken ghrelin: purification, cDNA cloning, and biological activity. Endocri nology. 143, 3454-3463.

Kojima, M.; H. Hosoda; Y. Date; M. Nakazato; H. Matsuo and K. Kangawa (1999): Ghrelin is a growth hormone-releasing acylated peptide from stomach. Nature 402, 656660.

Korbonits, M.; A. Goldstone; M. Gueorguiev and A. Grossman (2004): Ghrelin-a hormone with multiple functions. Front Neuroendocrinol. Apr; 25(1): 27-68.

Masuda, Y.; T. Tanaka; N. Inomata; N. Ohnuma; S. Tanaka; Z. Itoh; H. Hosoda; M. Koji ma and K. Kangawa (2000): Gastric acid secretion and motility in rats. Biochemi cal and Biophyskal Research Communica tions 276, 905-908.

Moesgaard, SG.; B. Ahren; R. Carr; D. Gram; C. Brand; and F. Sundler (2004): Effects of high-fat feeding and fasting on ghrelin ex pression in the mouse stomach. $\mathrm{Re}$ gul.Pept. 15;120 (1-3) : 261-7.

Murray, CD.; m. Kamm; S. Bloom and A. Em manuel (2003): Ghrelin for gastroenterologist: history and potential. Gastroentrolo gy.Nov;125,(5):1492-505.

Nakazato, M.; N. Murakami; Y. Date; M. Kojima; $H$. Matsuo; K. Kangawa and S. Matsu kura (2001): A role for ghrelin in the central regulation of feeding. Nature 409, 194198.

Pfeiffer, C. J.; G. Rowden and J. Weibel (1975): Gastrointestinal ultrastructure. Georg Thieme Publishers Stuttgart Igaku Shoin Ltd. Tokyo.

Reiko, W.; S. Ichiro; K. Hiroyuki; N. Kazuaki; H. Yujiro; K. Kenji and S. Takafumi (2002): Existence of ghrelin-immunopositive and expressing cells in the proventriculus of the hatching and adult chicken. Regulatory Peptides 111, 123-128.

Sakai, T. M. Satoh; H. Koyama; K. Iseki; M. Umahara; K. Fujikura and Z. Ito (1994): Localization of motilin-immunopositive cells in the rat, intestine by light micro scopic immunocytochemistry. Peptides 15, 987-991.

Sakata, I.; T. Tanaka; M. Matsubara; M. Yama zaki; S. Tani1; Y. Hayashi; K. Kangawa and T. Sakai (2002): Postnatal changes in ghrelin mRNA expression and in ghrelin- producing cells in the rat stomach. Journal of Endocinology. 174, 463471

Salem, H. F. (1982): Morophological studies of the oesophagus and stomach in growing Su danese ducks. M. V. Sc. Thesis presented to the Faculty of Vet. Med., Zagazig Uni versity.

Seham, A. H. (2004): Histological and histochemi cal studies on the gastrointestinal mucosa of the ostrich ( Struthio camelus ) PH. D. Thesis, Fac. Vet, Med. Suez Canal Uni versity.

Seoane, LM.; S. Tovar; R. Baldelli; E. Arvat; E. Ghigo; FF. Casanueva and C. Diequez (2000): Ghrelin elicits a marked stimulato ry effect on $\mathrm{GH}$ secretion in freely-moving rats. European Journal a/Endocrinology 143, R7-R9.

Shafika, A. R. M. (1989): Some histological and histochemical studies on the oesophagus and stomach of pigeon (Columbia livea) with reference to age vartation. M. V. Sc. Thesis, Fac. Vet, Med. Zagazig University.

Takahiro, H.; M. Kazuyo; M. Kazutaka; N. Ma sugi; N. Masamitsu; S. Muhtashans; $H$. Youitiro; K. Masayasu; K. Kenji and M. Noboru (2001): Ghrelin in domestic ani mals: distribution in stomach and its possi ble role. Domestic Animal Endocrinology 21, 17-24.

Tamura, H.; J. Kamegai; T. Shimizu; H. Sugiha ra and S. Oikawa (2002): Ghrelin stimu lates $\mathrm{GH}$ but not food intake in arcuate nucleus ablated rats. Endocrinology. 143, 3268-3275,

Tannenbaum, GS.; and CY. Bowers (2001): Inte ractions of growth hormone secretagogues and growth hormone-releasing hor mone/somatostatin. Endocrine. 14, 2127.

Tolle, V.; P. Zizzan; C. Tomasctto; M.C. Rio; J. Epelbaum and M.T. Bluec-Pajor (2001): In vivo and in vitro effects of ghre lin/motilinrelated peptide on growth hor mone se cretion in the rat. Neuroendocri nology. 73, 54-61.

Wren, AM. C. Small; C. Fnhhens; N. Neary; $H$. Ward; L. Seal; M. Ghatei and S. Bloom (2002): The hypothalamic mechanism of the hypophysiotropic action of ghrelin. Neuroendocrinology. 76, 316-324.

Wren, AM.; C. Small; H. Ward; K. Murphy; C. Dakin; S. Taheri; A. Kennedy; G. Ro berts; D. Morgan; M. Ghatel and $S$. Bloom (2000): The novel hypothalamic peptide ghrelin stimulates food intake and growth hormone secretion. Endocrinology 141, 4325-4328. 
Yamazaki, M.; K. Nakamura; H. Kobayashi; M. Matsubara; Y. Hayashi; K. Kangawa and T. Sakai (2002) Regulational effect of ghrelin on growth hormone secretion from perifused rat anterior pituitary cells. Journal of Neuroendocrinology. 14, 156-162.
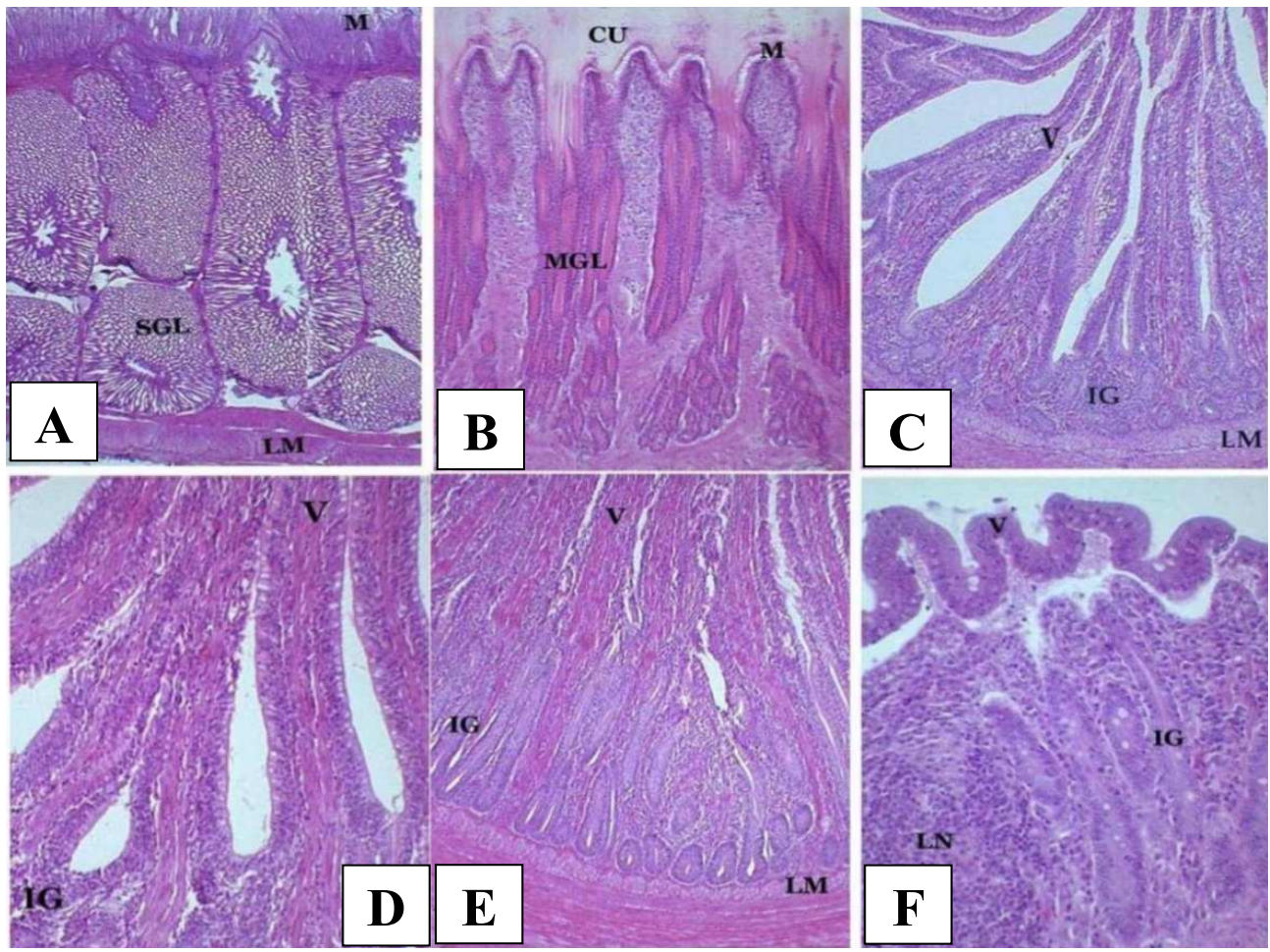

Fig (1):

A : A Photomicrograph of goose proventriculus showing mucosa (M), submucosal gland (SGL) \& lamina muscularis (LM) .Mag .X 50 Stain : H\&E.

B : A Photomicrograph of goose gizzard showing cuticle (CU), mucosa (M) \& mucosal gland (MGL) .Mag .X 200 Stain : H\&E.

C : A Photomicrograph of goose duodenum showing intestinal villi (V), intestinal gland (IG) \& lamina muscularis (LM) .Mag .X 100 Stain : H\&E

D : A Photomicrograph of goose jejunum showing intestinal villi (V) \& intestinal gland (IG) .Mag .X 200 Stain : H\&E.

E : A Photomicrograph of goose ileum showing intestinal villi (V), intestinal gland (IG), lamina muscularis (LM) \& tunica muscularis (TM).Mag .X 100 Stain : H\&E.

F : A Photomicrograph of goose caecum showing intestinal villi (V), intestinal gland (IG) \& lymphatic nodule (LN) .Mag .X 200 Stain : H\&E.

J. vet. anat.

Vol 1 No1, (2008) 14 - 21 

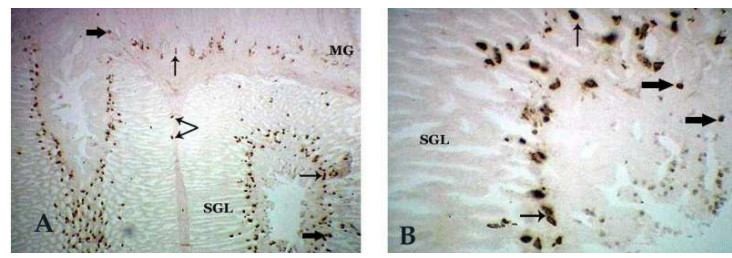

Fig(2): A : A Photomicrograph of goose proventriculus showing ghrelin (ip) cells in the mucosal gland ( MG) \& submucosal gland (SGL) as closed cells ( rounded) ( thick arrow ) \& open cells ( pyramidal or triangular ) (thin arrow ).Mag .X 100 .

B : A Photomicrograph of goose proventriculus showing ghrelin (ip) cells in the submucosal gland (SGL) as closed cells ( rounded) ( thick arrow ) \& open cells ( pyramidal or triangular ) (thin arrow ) .Mag .X 400 .
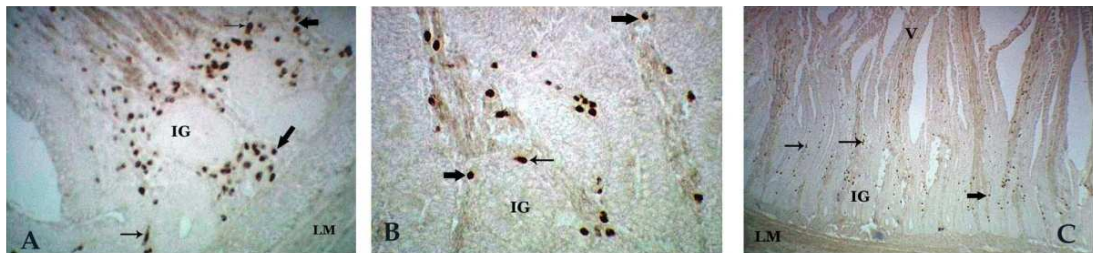

Fig (3): A Photomicrograph of goose showing ghrelin (ip) cells as closed cells ( rounded) ( thick arrow ) \& open cells ( pyramidal or triangular ) (thin arrow ) in A : Duodenum .Mag .X 400.

$\mathrm{B}$ : Jejunum Mag X $400 \mathrm{C}$ : lleum Mag X 100 intestinal villi (V), intestinal gland (IG) \& lamina muscularis (LM) .
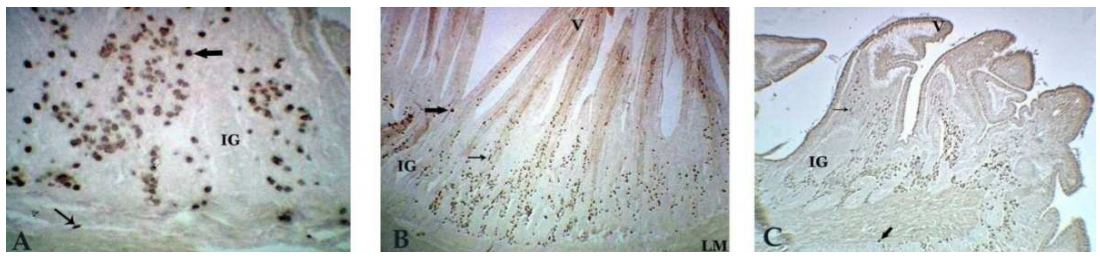

Fig(4): A Photomicrograph of goose showing ghrelin (ip) cells as closed cells ( rounded) ( thick arrow ) \& open cell (pyramidal or triangular) (thin arrow ) in A : Caecum .Mag .X 400 .

B: Colon Mag X 100 C: Rectum Mag X 100 intestinal villi (V) \& intestinal gland (IG) .
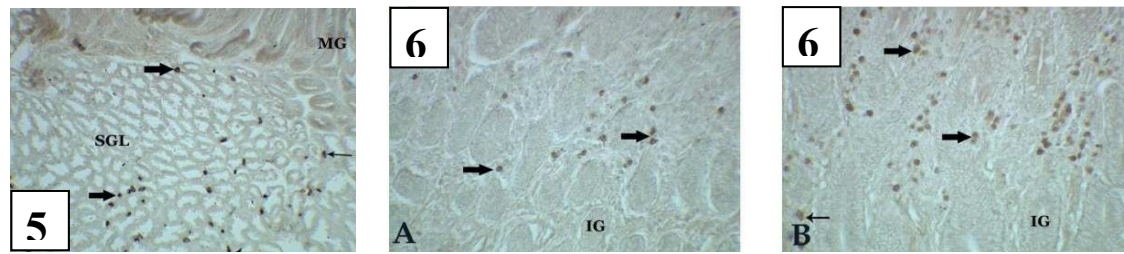

Fig(5): A Photomicrograph of duck proventriculus showing ghrelin (ip) cells in the mucosal gland ( MG) \& submucosal gland (SGL) as closed cells ( rounded) ( thick arrow ) \& open cells ( pyramidal or triangular ) (thin arrow ).Mag .X 100 .(left)

Fig(6): A Photomicrograph of duck showing ghrelin (ip) cells as closed cells ( rounded) ( thick arrow ) \& open cells ( pyramidal or triangular) (thin arrow) in the intestinal gland (IG) of $A$ : Jejunum

B: lleum Mag X 400 .(middle and right)

J. vet. anat. 

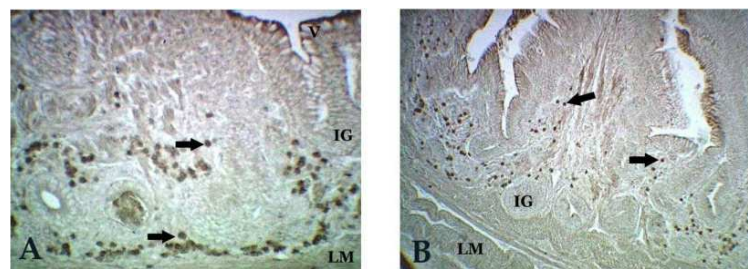

Fig(7): A Photomicrograph of duck showing ghrelin (ip) cells as closed cells ( rounded) ( thick arrow ) \& open cells ( pyramidal or triangular ) (thin arrow) in A : Colon

B: Rectum Mag X 200 .in intestinal villi (V), intestinal gland (IG) \& lamina mscularis (LM) .
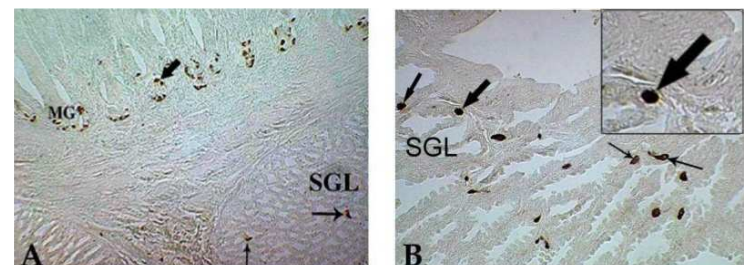

Fig (8): A : A Photomicrograph of chicken proventriculus showing ghrelin (ip) cells in the mucosal gland (MG) \& submucosal gland (SGL) as closed cells ( rounded) ( thick arrow ) \& open cells ( pyramidal or triangular ) (thin arrow) .Mag .X 100 .

$B$ : A Photomicrograph of chicken proventriculus showing ghrelin (ip) cells in the submucosal gland (SGL) as closed cells ( rounded) ( thick arrow ) \& open cells ( pyramidal or triangular ) (thin arrow ) .Mag .X 400 .
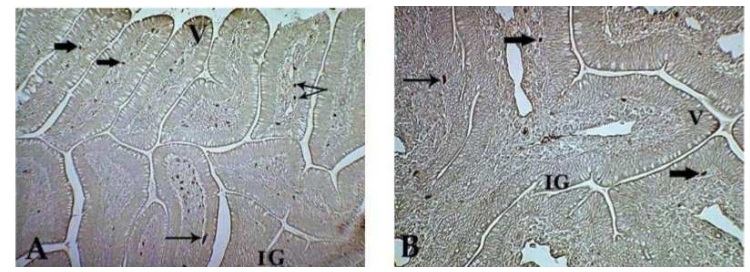

Fig (9): A Photomicrograph of chicken showing ghrelin (ip) cells as closed cells ( rounded) ( thick arrow ) \& open cells ( pyramidal or triangular ) (thin arrow ) in the intestinal gland (IG) of A : Jejunum Mag X 200 B: lleum Mag X 400 .intestinal villi (V) \& intestinal gland (IG) .
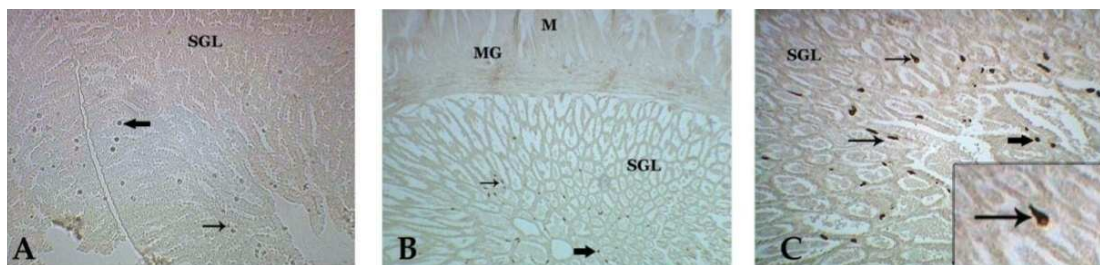

Fig (10): A Photomicrograph of proventriculus showing ghrelin (ip) cells as closed cells ( rounded) (thick arrow ) \& open cells ( pyramidal or triangular) (thin arrow ) in the intestinal gland (IG) of A : quail Mag X 200 B: Ostrich Mag X 100 C: Ostrich Mag X 400 . mucosa (M), mucosal gland (MG) \& submucosal gland (SGL) .

J. vet. anat.

Vol 1 No1, (2008) 14 - 21 